\title{
Immunomodulatory effect of an isolated fraction from Tinospora crispa on intracellular expression of INF- $\gamma$, IL-6 and IL-8
}

Walaa Najm Abood ${ }^{1,2}$, Iman Fahmi ${ }^{3}$, Mahmood Ameen Abdulla $^{1^{*}}$ and Salmah Ismail ${ }^{4}$

\begin{abstract}
Background: Immunomodulators are substances that modify immune system response to a threat. Immunomodulators modulate and potentiate the immune system, keeping it highly prepared for any threat. The immunomodulatory effect of the traditional medicine Tinospora crispa is investigated in this work.

Methods: T. crispa ethanol extract was fractionated by using different solvents. The ethanol extract and effective isolated fraction were used to investigate the potential immunomodulatory effect of different $T$. crispa doses ranging from $25 \mu \mathrm{g} / \mathrm{mL}$ to $1000 \mu \mathrm{g} / \mathrm{mL}$ on RAW 246.7 cells by detecting intracellular INF- $\gamma$, IL-6, and IL-8 expressions. The antioxidant activity of T. crispa was evaluated through FRAP and DPPH. The total phenolic and total flavonoid contents were also quantified.
\end{abstract}

Results: Results show that T. crispa extract has higher antioxidant potential than ascorbic acid. The FRAP value of T. crispa extract is $11011.11 \pm 1145.42 \mu \mathrm{mol} \mathrm{Fe} / 2 / \mathrm{g}$, and its DPPH inhibition percentage is $55.79 \pm 7.9$, with $22 \mu \mathrm{g} / \mathrm{mL}$ IC50. The results also reveal that the total phenolic content of T. crispa extract is 213.16- $\pm 1.31 \mathrm{mg}$ GAE/g dry stem weight, and the total flavonoid content is $62.07- \pm 39.76 \mathrm{mg}$ QE/g dry stem weight. T. crispa crude extract and its isolated fraction significantly stimulate RAW264.7 cell viability $(P \leq 0.05)$ and intracellular INF- $\gamma$, IL-6, and IL-8 expressions. The results of LC-MS show that four of the active compounds detected in the T. crispa isolated fraction are cordioside, quercetin, eicosenoic acid (paullinic acid), and boldine.

Conclusions: The results of this study obviously indicate that T. crispa has immunomodulatory effects through the stimulation of INF- $\gamma$, IL-6, and IL-8 expressions. LC-MS phytochemical analysis showed that the T. crispa fraction has cordioside, quercetin, eicosenoic acid (paullinic acid), and boldine, which may be responsible for the immunostimulator effect of T. crispa.

Keywords: IL-6, IL-8, Immunomodulatory, INF- $\gamma$, Tinospora crispa

\section{Background}

The immune system is a remarkably developed defense system that protects vertebrates from foreign bodies. The immune system produces many cells and molecules that distinguish and eliminate foreign and unwanted agents. The modulation of the immune system refers to any alteration in the immune response, including stimulation, expression, amplification, or inhibition of any portion or stage of the immune response. Therefore,

\footnotetext{
*Correspondence: Mahmood955@yahoo.com

'Department of Biomedical Science, Faculty of Medicine, University of Malaya, 50603 Kuala Lumpur, Malaysia

Full list of author information is available at the end of the article
}

immunomodulators are substances used for their effects on the immune system. Immunomodulators are grouped into two types based on their effects: immunostimulators and immunosuppressors. These immunomodulators mount an immune response or defend against pathogens or tumors [1]. Immunomodulators are substances that modify the response of the immune system to a threat. Immunomodulators modulate and potentiate the immune system, keeping it highly prepared for any threat [2].

Plant extracts are commonly investigated in different parts of the world for their possible immunomodulatory properties [3]. For example, Acorus calamus rhizome extract inhibits the growth of several human 
and mouse cell lines. This extract also inhibits nitric oxide, interleukin-2 (IL-2) and tumor necrosis factor- $\alpha$ (TNF- $\alpha$ ) production, as well as downregulates CD25 marker expression [4]. Many plant-derived compounds, such as sterols, sterolins, polysaccharides, alkaloids, flavonoids, lectin, and glycoproteins, are used as immunomodulators $[5,6]$.

The modulation of the immune response to treat diseases has long been attracting attention. Numerous recent studies have made advances in the research on ethnomedicinal plants as immunomodulatory agents. Immunopharmacology is a relatively new developing branch of pharmacology that aims to identify immunomodulators. The possible uses of immunomodulators in clinical medicine include the reconstruction of immune deficit, such as AIDS treatment, and the suppression of normal immune response or exaggerated immune response in autoimmune diseases. Medicinal plants and their active components are important sources of immunomodulators. The development of immunomodulatory and anti-tumor drugs from natural compounds has attracted considerable interest [3].

Plants provide humans with food, dyes, perfumes, gum, fibers, resins, and many other useful products. Ethno-pharmacologists are currently paying more attention to the investigation of the bioactive properties and phytochemical analysis of plants for the treatment of various diseases. Several medicinal plants serve therapeutic functions in various diseases [7].

Many studies recently endorsed the use of traditional medicinal plants to treat diseases. Plants reportedly possess various biological activities [8]. Genus Tinospora has been known as a traditional medicine in Southeast Asia. Tinospora has long been used in India as medication and in the preparation of a starch known as gilae-ka-sat or palo. Tinospora is a tonic, diuretic, and antiperiodic. Tinospora crispa, which is abundant in the Philippines under the name makabuhay, which means "You may live", can be easily used for general weakness, malarial fevers, and chronic rheumatism. The whole plant has the bitter alkaloid colombine, flavonoids, and a glucoside [9]. Previous studies were performed to evaluate the nutritional components and mineral content of T. crispa stems. Results reveal that $T$. crispa contains high moisture content of approximately $77.9 \%$ and carbohydrate content of about $19.4 \%$. Fat, protein, fiber, and ash are present in the plant at low percentages. The most abundant elements in the plant are calcium and potassium. Other trace elements, such as silicon, magnesium, chlorine, and phosphorus, are very low. The result also shows that $T$. crispa extracts have high antioxidant property. This result is confirmed by the existence of phenolics and flavonoids, such as catechin, luteolin, morin, and rutin, in the extract. These phenolics and flavonoids are responsible for high antioxidant activity.
Some studies suggest that $T$. crispa could be an important source of nutrients and natural antioxidants [10]. The various chemical components of $T$. crispa make it useful for the treatment of different diseases. Many studies support the use of $T$. crispa stem extract as an antiparasitic. T. crispa stem extract has been used in vivo as an antimalarial agent [11]. The antioxidant properties of T. crispa stem extract make it useful for the treatment of diseases resulting from oxidative stress, such as cardiovascular diseases [12]. T. crispa is traditionally known as an anticancer drug, such that many studies investigated the anticancer activity of the plant. T. crispa has dosedependent anti-proliferative activity against MDA-MB231 cancer cells, HeLa cells, and human mammary cancer cells (MCF-7) [13]. The aqueous crude extract of T. crispa stems has anti-proliferative activity against the MCF-7 cell line [14]. The immunomodulatory potential of the isolated T. crispa fraction is investigated in this work.

\section{Methods}

\section{Plant extraction}

T. crispa dried stems; Figure 1 (harvested at the Selangor housing area in the Herbarium of University Putra in Malaysia, as voucher specimens: KLU 45568) were crushed, and $100 \mathrm{~g}$ of the powder was placed in a conical flask and soaked in $900 \mathrm{~mL}$ of $95 \%$ ethanol for $3 \mathrm{~d}$ at room temperature $\left(30 \pm 2^{\circ} \mathrm{C}\right)$. The suspension was occasionally shaken to completely dissolve the powder in ethanol, which was denoted by the change in colour to dark brown. The mixture was then filtered using a filter paper (Whitman, $185 \mathrm{~mm}$ ), and distilled under reduced pressure in a rotary evaporator (Buchi, Switzerland). The extract was stored at $-20^{\circ} \mathrm{C}$ prior to use [15].

\section{Profiling and fractionation of crude extracts}

First, $1 \mathrm{~g}$ of ethanol crude extract was dissolved in $5 \mathrm{~mL}$ of methanol and was subjected to column chromatography

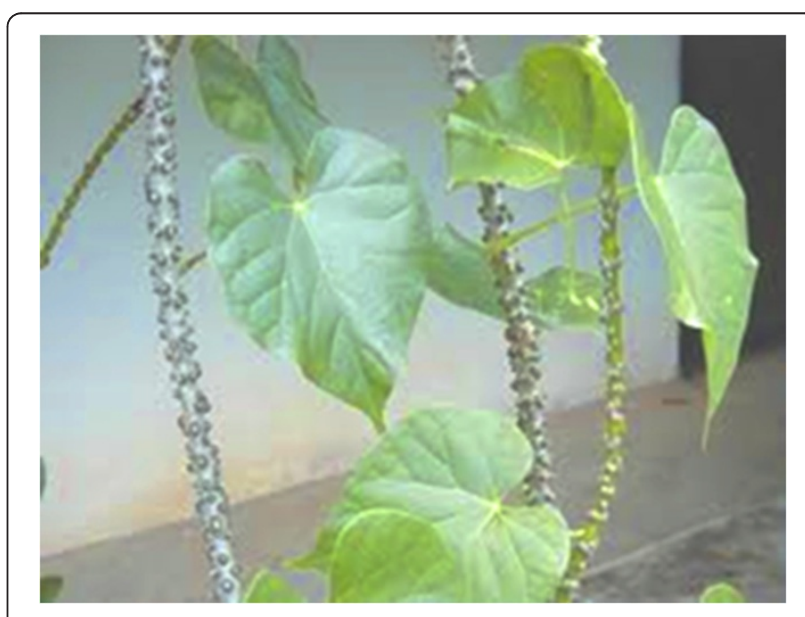

Figure 1 Tinospora crispa stem and leaves. 
fractionation in $3.0 \times 50 \mathrm{~cm}$ glass columns (Kontes Scientific Glassware, Vineland, NJ, USA) packed with silica gel G60, 70-230 mesh (Merck, Darmstadt, Germany) linked to an EYEL-L4 pump (Tokyo Rikakikai, Tokyo, Japan). Gradient concentrations of solvents that differ in polarity $(25 \mathrm{~mL}$ each of five different concentrations: $20 \%, 40 \%, 60 \%, 80 \%$, and $100 \%)$ were used to elute the crude extract. The solvents used were hexane, ethyl acetate, methanol, acetonitrile, and water in order of increasing polarity. The yield fractions were collected in clean class tubes and gathered based on the solvent used. The solvents were evaporated from the yield fractions under reduced pressure by using a centrifuge evaporator.

\section{Antioxidant and free radical study}

\section{Ferric reducing antioxidant power (FRAP)}

This method was performed by preparing the working FRAP reagent as described below:

1) The $300 \mathrm{mmol} / \mathrm{L}$ acetate ( $\mathrm{pH} 3.6)$ buffer was prepared by mixing $3.1 \mathrm{~g}$ of sodium acetate trihydrate $\left(\mathrm{C}_{2} \mathrm{H}_{3} \mathrm{NaO}_{2}: 3 \mathrm{H}_{2} \mathrm{O}\right)$ with $16 \mathrm{~mL}$ of glacial acetic acid/L of buffer solution.

2) The TPTZ solution was prepared by dissolving $10 \mathrm{mmol} / \mathrm{L} \mathrm{TPTZ}$ in $40 \mathrm{mmol} / \mathrm{L} \mathrm{HCl}$.

3) We mixed $20 \mathrm{mmol} / \mathrm{L} \mathrm{FeCl} \mathrm{H}_{3} \times 6 \mathrm{H}_{2} \mathrm{O}$ with distilled water.

4) The three reagents were mixed to a $10: 1: 1$ ratio by adding $25 \mathrm{~mL}$ of the acetate buffer, $2.5 \mathrm{~mL}$ of the TPTZ solution, and $2.5 \mathrm{~mL}$ of the $\mathrm{FeCl}_{3} \times 6 \mathrm{H}_{2} \mathrm{O}$ solution. The working solution must always be freshly prepared.

5) Standards of known Fe(II) concentrations were prepared. $\left(\mathrm{FeSO}_{4}: 7 \mathrm{H}_{2} \mathrm{O}\right.$ ) was run in triplicate for calibration in several concentrations from $100 \mu \mathrm{mol} / \mathrm{L}$ to $1000 \mu \mathrm{mol} / \mathrm{L}$.

6) FRAP reagent was used as a blank. Approximately $150 \mu \mathrm{L}$ of the total FRAP reagent was added to each well in a 96-well $(300 \mu \mathrm{L})$ microplate. A $20 \mu \mathrm{L}$ portion of the sample was then added to each well in triplicate, and the absorbance at $593 \mathrm{~nm}$ was measured after $15 \mathrm{~min}$. The relative activities of the samples were assessed by comparing their activities with that of the $\mathrm{Fe}^{+2}$ equivalent [16].

\section{Redical scavenging activity test (DPPH)}

The test was performed according to previous studies [15]. The plant extract (1 mg) was dissolved in $1 \mathrm{~mL}$ of 95\% ethanol to make a stock solution, and five dilutions were prepared from the stock. L-Ascorbic acid standards were prepared similar to the plant extracts. Approximately $5 \mu \mathrm{L}$ from each dilution of plant extracts and standard was added to $195 \mu \mathrm{L}$ of DPPH, and the mixture was loaded in a 96-well plate in triplicate for each sample. Ethanol was used as a blank. The plate was incubated at room temperature for $2 \mathrm{~h}$, and the absorbance was read at $517 \mathrm{~nm}$.

The antioxidant activity was calculated as the DPPH radical scavenging activity (DPPH inhibition \%) according to the formula:

$$
\begin{aligned}
\mathrm{DPPH} \text { inhibition } \%= & {[(\text { absorbance blank-absorbance }} \\
& \text { sample }) / \text { absorbance blank }] \times 100
\end{aligned}
$$

The graph of the concentration of the sample versus the DPPH scavenging activity percentage was plotted to evaluate IC50 (the concentration required to inhibit 50\% of the DPPH radical scavenging activity).

\section{Total phenolic content}

The total phenolic contents were determined as described in [17], with some modifications in the solution volumes to make them suitable for the microplate. A $10 \mu \mathrm{L}$ portion from the extract prepared at $1 \mathrm{mg} / \mathrm{mL}$ concentration was added to $100 \mu \mathrm{L}$ of Folin-Ciocalteu reagent (prepared beforehand at tenfold dilution with deionized water), then mixed well and set aside for $5 \mathrm{~min}$ at room temperature. Then, $100 \mu \mathrm{L}$ of $10 \%$ sodium carbonate was added to the mixture, which was then incubated for $2 \mathrm{~h}$ at room temperature. The optical density was read at $765 \mathrm{~nm}$ absorbance. Gallic acid was used as the standard. The standard calibration $(0 \mathrm{mg} / \mathrm{mL}$ to $200 \mathrm{mg} / \mathrm{mL}$ ) curve was plotted using gallic acid. The total phenolic content is expressed as gallic acid equivalent in $\mathrm{mg} / \mathrm{g}$ of dry sample or $\mathrm{mg}$ GAE/g sample.

\section{Estimation of total flavonoid content}

The aluminum chloride colorimetric method was used as described by [18] to determine flavonoid content. The method was applied by mixing $0.5 \mathrm{~mL}$ of plant extract (1 $\mathrm{mg} / \mathrm{mL}), 1.5 \mathrm{~mL}$ of methanol, $0.1 \mathrm{~mL}$ of $10 \%$ aluminum chloride, $0.1 \mathrm{~mL}$ of $1 \mathrm{M}$ potassium acetate, and $2.8 \mathrm{~mL}$ of distilled water. The mixture was set aside at room temperature for $30 \mathrm{~min}$. The absorbance of the mixture was measured at $415 \mathrm{~nm}$. A calibration curve was established to calculate total flavonoid content. The calibration curve was plotted by preparing different concentrations $(0 \mathrm{mg} / \mathrm{mL}$ to $200 \mathrm{mg} / \mathrm{mL})$ of quercetin in methanol. The total flavonoid content is expressed as quercetin equivalent in $\mathrm{mg} / \mathrm{g}$ of dry sample or $\mathrm{mg} \mathrm{QE} / \mathrm{g}$ sample.

\section{Immunomodulatory effect in vitro \\ Cell line}

A murine macrophage cell line RAW264.7 obtained from American Type Culture Collection (ATCC, Rockville, MD) was cultured in DMEM supplemented with $4500 \mathrm{~g}$ 
of glucose/L, $110 \mathrm{mg}$ of sodium pyruvate/L, 1\% penicillin-streptomycin (Sigma-Aldrich, UK), and 10\% heatinactivated fetal bovine serum (FBS) (J R Scientific, Inc., USA). The cells were cultured at $37^{\circ} \mathrm{C}$ in a $5 \% \mathrm{CO}_{2}$ atmosphere incubator (NuAire, Plymouth, MN, USA). The cells were subcultured when at $80 \%$ confluence, and the cell suspension was diluted to $5 \times 10^{5}$ cells $/ \mathrm{mL}$ for the experiments [19]. One hour before the experiments, $1 \mathrm{~mL}$ of fresh medium $\left(37^{\circ} \mathrm{C}\right)$ was placed on the six-well plates (Costar, Corning, NY). The cells were cultured for $24 \mathrm{~h}$.

\section{Proliferation assay}

The 3-(4,5-dimethylthiazol-2-yl)-2,5-diphenyltetrazolium bromide (MTT) assay (Merck, Germany) was used to determine the effect of plant extract and isolated fractions on RAW264.7 cell proliferation. The MTT test measures the capability of cells to convert MTT to formazan. The cells were plated in 96-well tissue culture plates at a density of $5 \times 10^{5}$ cells $/ \mathrm{mL}, 5000$ cells/well in complete DMEM medium and incubated in triplicate in a 96-well plate at a final volume of $100 \mu \mathrm{L}$ for $24 \mathrm{~h}$ at $37^{\circ} \mathrm{C}$ and $5 \% \mathrm{CO}_{2}$ conditions [20]. The cells were treated with plant crude extract, and all fractions at the final concentrations of 25, 50, 100, 200, 400, 800 and $1000 \mu \mathrm{g} / \mathrm{mL}$ were incubated for $24 \mathrm{~h}$ at $37^{\circ} \mathrm{C}$ and $5 \%$ $\mathrm{CO}_{2}$. Then, $10 \mu \mathrm{L}$ of $5 \mathrm{mg} / \mathrm{mL}$ phosphate-buffered saline (PBS) MTT solution was added to each well. After $4 \mathrm{~h}$ of incubation at $37^{\circ} \mathrm{C}$, the media and MTT were aspirated, and $100 \mu \mathrm{L}$ of dimethyl sulfoxide (Fisher Scientific, UK) was added to dissolve the yellow MTT tetrazolium salt produced by metabolism to acquire purple MTT formazan salt. The amount of MTT formazan salt produced is proportional to the amount of viable cells, and the cell proliferation rate is determined by measuring the absorbance at $570 \mathrm{~nm}$ using a microplate reader $[19,21]$.

\section{In vitro stimulation for intracellular cytokines production}

The capability of the isolated fraction to stimulate cytokine production in the RAW 264.7 cell was evaluated. RAW 264.7 cells $\left(1 \times 10^{6}\right.$ cells $/ \mathrm{mL}, 6 \mathrm{~mL} /$ well $)$ were incubated in a complete DMEM medium for $24 \mathrm{~h}$ at $37^{\circ} \mathrm{C}$ in $5 \% \mathrm{CO}_{2}$ [22]. The cells were treated with $1 \mu \mathrm{g} / \mathrm{mL}$ of LPS (Escherichia coli 055: B5, Difco, Detroit, MI,USA), $1 \mu \mathrm{L} / \mathrm{mL}$ of brefeldin A (BD GolgiPlug ${ }^{\mathrm{TM}}$ ), $100 \mu \mathrm{g} / \mathrm{mL}$ of T. crispa stem crude extract, and its more effective fraction $100 \mu \mathrm{g} / \mathrm{mL}$ (T.c F2). The cells were incubated for $6 \mathrm{~h}[19,23]$. The medium was removed before treatment with $1 \mu \mathrm{g} / \mathrm{mL}$ of LPS, and cells were washed with $5 \mathrm{~mL}$ of PBS and replenished with complete medium [24]. Cells treated with $1 \mu \mathrm{g} / \mathrm{mL}$ LPS alone were used as the control [22]. After incubation, the cells were washed twice with PBS and resuspended in $0.5 \mathrm{~mL}$ of staining buffer PBS containing 1\% FBS and $0.09 \%$ (w/v) sodium azide [23].

\section{Flow cytometry immunostaining of intracellular cytokines} Cells were resuspended to $10^{7}$ cells $/ \mathrm{mL}$ density, and $100 \mu \mathrm{L}$ aliquots of the cell suspension were transferred into tubes for staining. The cell suspension was preincubated with Mouse BD Fc Block ${ }^{\mathrm{TM}}$ purified anti-mouse CD16/CD32 mAb 2.4G2 (BD Fc Block ${ }^{\mathrm{Tm}}$; Cat. No. $553141)\left(1 \mu \mathrm{g} / 10^{6}\right.$ cells in $\left.100 \mu \mathrm{L}\right)$ at $4^{\circ} \mathrm{C}$ for $15 \mathrm{~min}$ to reduce nonspecific immune fluorescence staining, and the cells were fixed/permeabilized with $250 \mu \mathrm{L}$ of fixation/permeabilization solution (BD Cytofix/Cytoperm $^{\mathrm{TM}}$ Plus Fixation/Permeabilization, BD Golgi Plug ${ }^{\mathrm{TM}}$ protein transport inhibitor, Cat. No.555028) for $20 \mathrm{~min}$ at $4^{\circ} \mathrm{C}$. The cells were washed twice with $1 \mathrm{~mL}$ of $1 \times$ BD Perm $/$ Wash ${ }^{\mathrm{Tm}}$ buffer, $250 \times \mathrm{g}$, for $5 \mathrm{~min}$ at $4^{\circ} \mathrm{C}$. The fixed/permeabilized cells were resuspended in $50 \mu \mathrm{L}$ of BD Perm/Wash ${ }^{\mathrm{Tm}}$ buffer and then incubated with fluorochrome-conjugated anti-cytokine antibodies, PE Anti-Mouse IL-6 $(\leq 0.25 \mu \mathrm{g} /$ million cells, BD Cat. No: 554401), FITC Rat Anti-Mouse IFN- $\gamma(\leq 0.5 \mu \mathrm{g} / \mathrm{million}$ cells, BD Cat. No: 554411), and APC Rat Anti-Mouse IL-8 $(\leq 0.5 \mu \mathrm{g} /$ million cells, BD Cat. No: FAB2164A) at $4^{\circ} \mathrm{C}$ for $30 \mathrm{~min}$ in the dark. The cells were washed twice with $1 \times$ BD Perm/Wash ${ }^{\mathrm{Tm}}$ buffer (1 mL/wash) after incubation and then resuspended in staining buffer before flow cytometric analysis.

\section{Identification of active constituents}

High-resolution mass spectrometry was performed to identify and characterize the active constituents in the T. crispa fraction 2 (T. c F2) that has proliferation and stimulation effects on RAW264.7 cells. High-resolution mass spectra were recorded on an LC-Mass (Agilent technologies 6530 Accurate-Mass QTOF LC/MC), using $\mathrm{MeOH}-$ Water (40:60) as the eluent. The high resolution mass spectra confirms the identity of the extracted active compounds using $[\mathrm{M}+\mathrm{H}]^{+},[\mathrm{M}+\mathrm{Na}]^{+},[\mathrm{M}+\mathrm{K}]^{+}$, and $\left[\mathrm{M}+\mathrm{NH}_{3}\right]^{+}[25]$

\section{Statistical analysis}

The values are presented as mean \pm standard division (S.D.). The data are statistically analyzed through one-way analysis of variance (ANOVA), univariate analysis of variance, and post hoc LSD test (comparing the treated groups with control), with $P \leq 0.05$ considered as statistically significant.

The flow cytometry samples were analyzed using the two-dimensional forward and side scatter of the flow cytometer and fluorescence intensity using at least 10,000 cells collected from each sample. The cytokine analysis was performed using FACS Canto II flow cytometer and FACS Diva Version 6.1.3 software (BD Biosciences). 


\section{Results}

Quantitative and evaluation of antioxidant contents and activity

The antioxidant activity of $T$. crispa, as evaluated by FRAP and DPPH tests, are shown in Table 1. The total phenolic and total flavonoid contents are also presented in Table 1. The results show that the T. crispa extract has higher antioxidant activity than standard ascorbic acid. The FRAP value of the T. crispa extract is $11011.11 \pm 1145.42 \mu \mathrm{mol} \mathrm{Fe} \mathrm{F}^{+2} / \mathrm{g}$, whereas the value for standard ascorbic acid is $7951.85 \pm 330.42 \mu \mathrm{mol}$ $\mathrm{Fe}^{+2} / \mathrm{g}$. The DPPH test detected $55.79 \pm 7.9 \% \mathrm{DPPH}$ inhibition, and $22 \mu \mathrm{g} / \mathrm{mL}$ IC50 for T. crispa, and $69.03 \pm$ 9.3\% DPPH inhibition and $19 \mu \mathrm{g} / \mathrm{mL}$ IC50 for ascorbic acid. The results reveal that the total phenolic content of the $T$. crispa extract is $213.16 \pm 1.31 \mathrm{mg}$ GAE/g dry stem weight and its total flavonoids content is $62.07 \pm 39.76 \mathrm{mg}$ QE/g dry stem weight.

\section{Proliferation effect on the RAW264.7 cell}

The immunomodulatory effect of the crude extract and five yield fractions of the plant on the RAW264.7 macrophage cell line was investigated. The results prove that $T$. crispa stimulates RAW264.7 cell proliferation in a dose-dependent manner. Cell viability significantly increased $(P \leq 0.05)$ with mean viable cell percent \pm SD values of $126.43 \pm 2.91,141.59 \pm 1.8$, $163.62 \pm 3.26,131.28 \pm 0.65,127.96 \pm 1.45$, and $108.18 \pm$ 1.98 for $25,50,100,200,400$, and $800 \mu \mathrm{g} / \mathrm{mL}$ T. crispa doses, respectively. The results show no significant increase in the cell viability at $1000 \mu \mathrm{g} / \mathrm{mL}$ T. crispa $(103.79 \pm 1.79)$ dose after incubation for $24 \mathrm{~h}$ compared with the control (Figure 2).

The immunomodulatory effect of the isolated fractions on the RAW264.7 cell line was investigated, and the best fraction was chosen to investigate its effect on the intracellular expression of cytokines and was subjected to LCMS profiling to identify the active constituents. The effects of the five fractions of the plant on RAW264.7 cell line proliferation were investigated. The isolated fractions appear to have different effects on RAW264.7 cell proliferation. The T. crispa (F1, F2, and F5) treatments show significant dose-dependent cell viability increase $P \leq 0.05$. The viability percentage significantly decreased $P \leq 0.05$ in a dose dependent manner compared with the control untreated cells

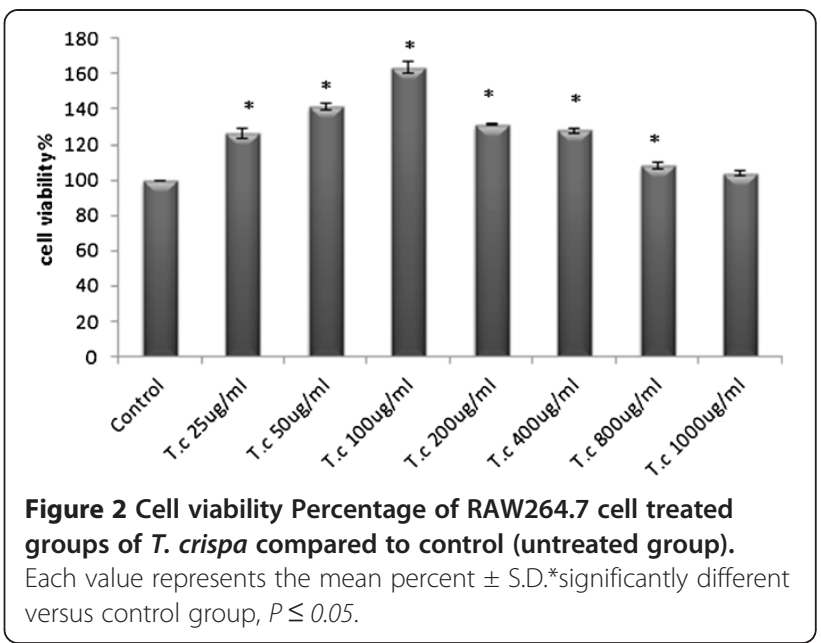

after the treatment of $24 \mathrm{~h}$ incubation with $T$. crispa (F3 and F4) (Figure 3).

In vitro stimulation of intracellular cytokines production The stimulation of intracellular INF- $\gamma$, IL-6, and IL-8 production were measured by flow cytometry on the RAW264.7 macrophage cell stimulated with $1 \mu \mathrm{g} / \mathrm{mL}$ of LPS and $100 \mu \mathrm{g} / \mathrm{mL}$ of each T. crispa extract and T. crispa F2. The intracellular INF- $\gamma$ expression significantly $(P \leq 0.05)$ increased RAW264.7 cell stimulation with $T$. crispa extract and T. crispa F2 at mean percent \pm SD $23.15 \pm 4.25$ and $22.95 \pm 4.35$, respectively, compared with the control RAW264.7 cells treated with LPS alone (Figure 4).

The results also show significant $(P \leq 0.05)$ increase in intracellular IL-6 and IL-8 expressions with the RAW264.7 cells treated with T. crispa extract and T. crispa F2. Figure 5 shows that the mean percent \pm SD for intracellular IL-6 expression are $13.67 \pm 6.17$ and $13.90 \pm 5.53$ for $T$. crispa extract and T. crispa F2, respectively and Figure 6 shows that the mean percent \pm SD for intracellular IL-8 intracellular are $16.0 \pm 3.3$ and $15.9 \pm 2.5$ for $T$. crispa extract and $T$. crispa F2, respectively, compared with the control RAW264.7 cells treated with LPS alone.

\section{Investigation of active constituents}

LC-MS was performed to identify the phenolic constituents and other active compounds of T. crispa fraction 2.

Table 1 Antioxidant activity values, total phenolic and total flavonoids contents for T. crispa extract

\begin{tabular}{|c|c|c|c|c|c|}
\hline & \multirow{2}{*}{$\begin{array}{l}\text { FRAP assay } \mu \mathrm{mol} \\
\mathrm{Fe}+2 / \mathrm{mg}\end{array}$} & \multicolumn{2}{|c|}{ Redical scavenging assay } & \multirow{2}{*}{$\begin{array}{c}\text { Total phenolic } \\
\text { contents mg GAE/g }\end{array}$} & \multirow{2}{*}{$\begin{array}{l}\text { Total flavonoid } \\
\text { contents } \mathrm{mg} \mathrm{TE} / \mathrm{g}\end{array}$} \\
\hline & & DPPH inhibition \% & IC50 $\mu \mathrm{g} / \mathrm{ml}$ & & \\
\hline Ascorbic acid & $7951.85 \pm 330.42$ & $69.03 \pm 9.3$ & 19 & & \\
\hline T. crispa & $11011.11 \pm 1145.42$ & $55.79 \pm 7.9$ & 22 & $213.16 \pm 1.31$ & $62.07 \pm 39.76$ \\
\hline
\end{tabular}

Data here are expressed as mean \pm standard deviation, FRAP value is expressed asFe ${ }^{+2}$ equivalents IC50 value for the DPPH assay expressed as $\mu \mathrm{g} / \mathrm{ml}$. Total phenolic content is expressed as Gallic acid equivalents (GAE), while the Total flavonoid content is expressed as Trolox equivalents (TE). 


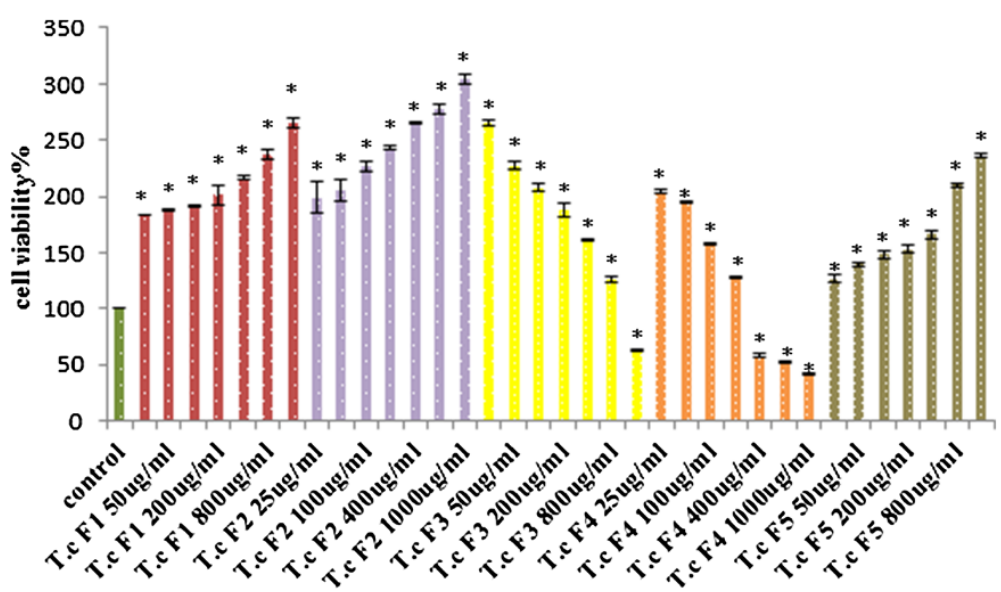

Figure 3 Cell viability Percentage of RAW264.7 cell treated groups of T. crispa (T. c) F1, F2, F3, F4 and F5 compared to control (untreated group). Each value represents the mean percent \pm S.D.* significantly different versus control group, $P \leq 0.05$.

Results show that approximately four compounds were detected for T. crispa F2. The results show all peaks detected with their retention times, observed $m / z$ and the $\mathrm{m} / z$ of fragment ions. The T. crispa F2 contains cordioside at $\mathrm{m} / \mathrm{z} 511.2712$ (Figure 7); quercetin at $\mathrm{m} / \mathrm{z}$ 301.1422 and its fragments at $\mathrm{m} / z 123.0913,185.1149$, and 155.1538 (Figure 8); eicosenoic acid (paullinic acid) at $m / z 311.1457$ (Figure 9); and boldine at $m / z 327.1576$ and its fragment at $m / z 251.1251$ (Figure 10).

\section{Discussion}

The modulation of immune response to combat diseases has long been a topic of interest. Many recent studies made progress in the research on ethnomedicinal plants as immunomodulatory agents. Immunopharmacology is a relatively new and developing branch of pharmacology that aims to discover immunomodulators. The possible uses of immunomodulators in medicine include the rehabilitation of immune deficiency. Plant extracts have

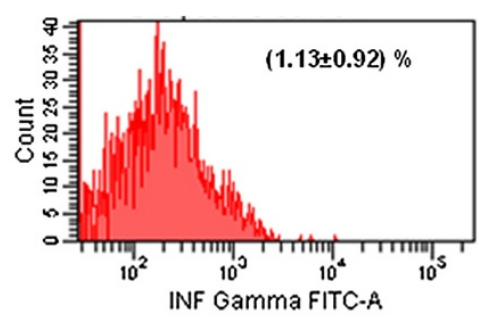

A : LPS $1 \mu \mathrm{g} / \mathrm{ml}$ (Control)

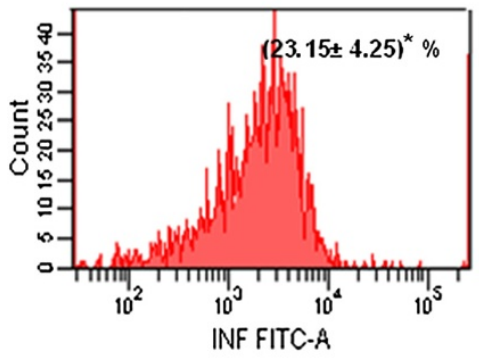

B: $\operatorname{LPS} 1 \mu \mathrm{g} / \mathrm{ml}+T$. crispa $100 \mu \mathrm{g} / \mathrm{ml}$

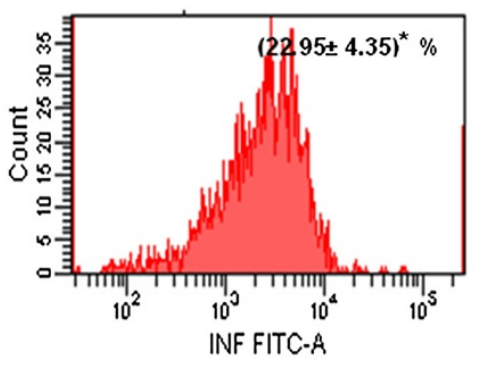

C: LPS1 $\mu \mathrm{g} / \mathrm{ml}+T$. crispa $\mathrm{F} 2100 \mu \mathrm{g} / \mathrm{ml}$

Figure 4 Intracellular expression of INF- $\gamma$ on RAW264.7 macrophage cell. Flow cytometry analysis was used to assess the intracellular expression of INF- $\gamma$. The figures show the expression percent of INF- $\gamma$ on RAW264.7 cell stimulated with (A) $1 \mu \mathrm{g} / \mathrm{ml}$ LPS alone as a control. (B) $1 \mu \mathrm{g} / \mathrm{ml} \mathrm{LPS}+$ T. crispa $100 \mu \mathrm{g} / \mathrm{ml}$. (C) LPS1 $\mu \mathrm{g} / \mathrm{ml}+$ T. crispa F2 $100 \mu \mathrm{g} / \mathrm{ml}$. The number was represented the mean percent of the cell \pm SD. *Significant $P \leq 0.05$ versus control. 


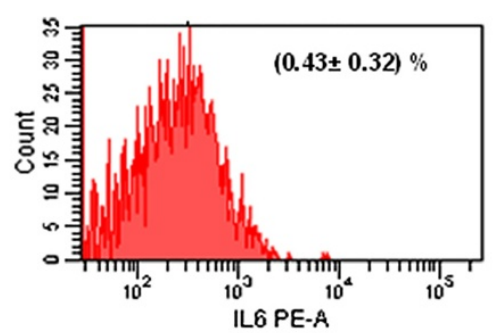

A: LPS $1 \mu \mathrm{g} / \mathrm{ml}$ (Control)

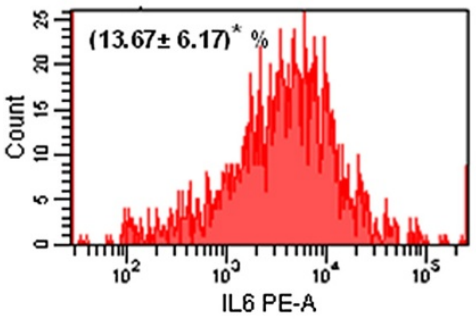

B: $\mathrm{LPS} 1 \mu \mathrm{g} / \mathrm{ml}+T$. crispa $100 \mu \mathrm{g} / \mathrm{ml}$

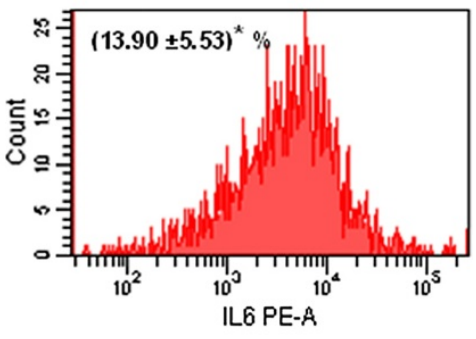

\section{C: $\operatorname{LPS} 1 \mu \mathrm{g} / \mathrm{ml}+T$. crispa $\mathrm{F2} 100 \mu \mathrm{g} / \mathrm{ml}$}

Figure 5 Intracellular expression of IL-6 on RAW264.7 macrophage cell. Flow cytometry analysis was used to assess the intracellular expression of IL-6. The figures show the expression percent of IL-6 on RAW264.7 cell stimulated with (A) $1 \mu \mathrm{g} / \mathrm{ml} \mathrm{LPS}$ alone as a control. (B) $1 \mu \mathrm{g} / \mathrm{ml}$ LPS + T. crispa $100 \mu \mathrm{g} / \mathrm{ml}$. (C) LPS1 $\mu \mathrm{g} / \mathrm{ml}+$ T. crispa F2 $100 \mu \mathrm{g} / \mathrm{ml}$. The number was represented the mean percent of the cell \pm SD. *Significant $\mathrm{P} \leq 0.05$ versus control.

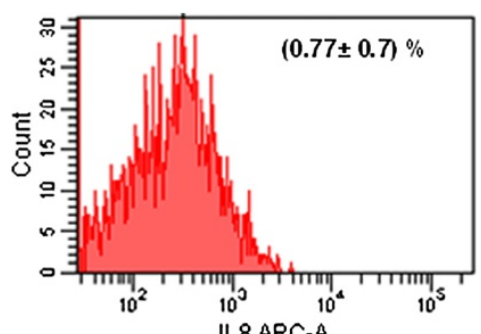

A: LPS $1 \mu \mathrm{g} / \mathrm{ml}$ (Control)

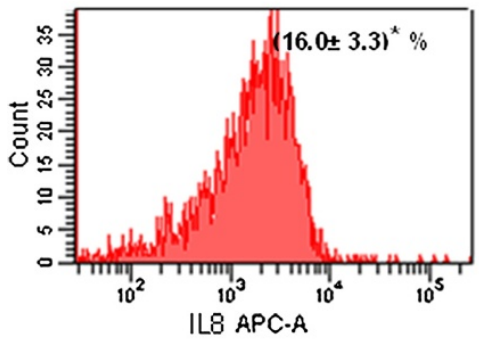

B: $\operatorname{LPS} 1 \mu \mathrm{g} / \mathrm{ml}+T$. crispa $100 \mu \mathrm{g} / \mathrm{ml}$

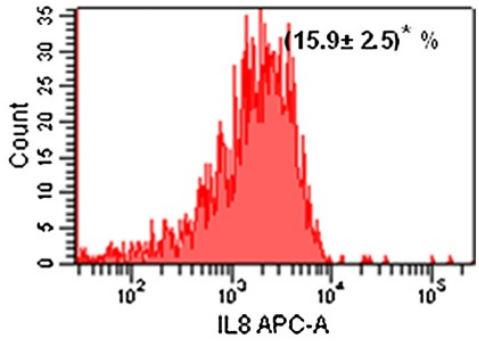

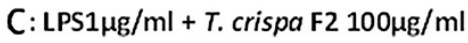

Figure 6 Intracellular expression of IL-8 on RAW264.7 macrophage cell. Flow cytometry analysis was used to assess the intracellular expression of IL-8. The figures show the expression percent of IL-8 on RAW264.7 cell stimulated with (A) $1 \mu \mathrm{g} / \mathrm{ml} \mathrm{LPS}$ alone as a control. (B) $1 \mu \mathrm{gg} / \mathrm{ml}$ LPS + T. crispa $100 \mu \mathrm{g} / \mathrm{ml}$. (C) LPS1 $\mu \mathrm{g} / \mathrm{ml}+$ T. crispa F2 $100 \mu \mathrm{g} / \mathrm{ml}$. The number was represented the mean percent of the cell \pm SD. ${ }^{*}$ Significant P $\leq 0.05$ versus control. 


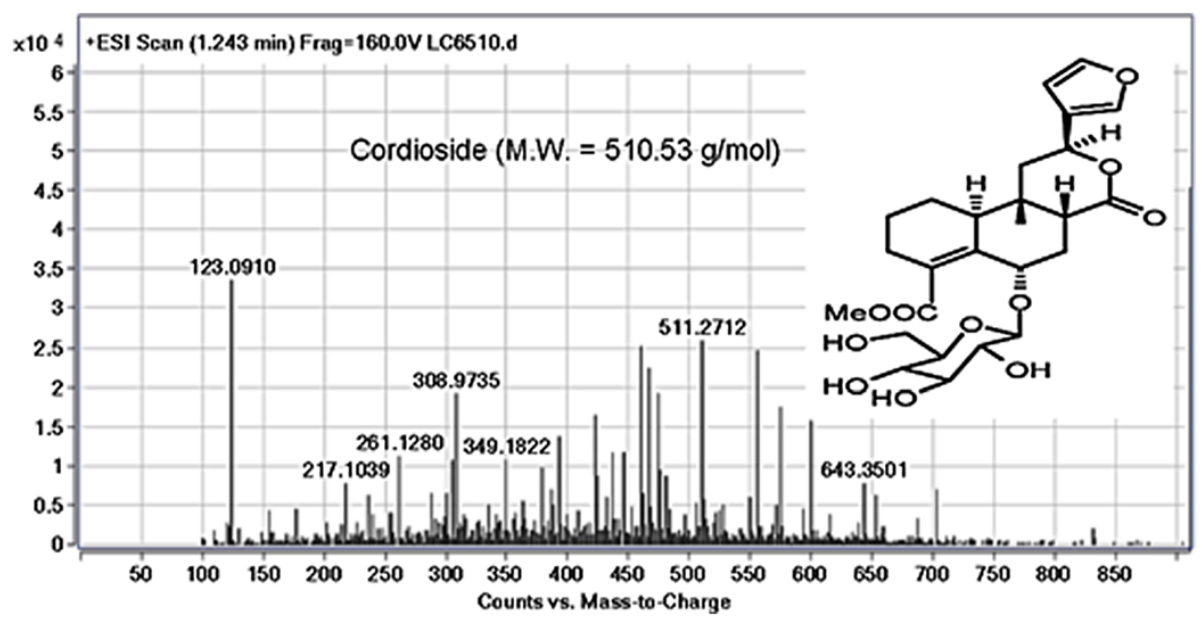

Figure 7 Mass spectrum (TOF MS ES+) and chemical structure of cordioside (peak No. 1) identified in T. crispa F2.

been widely investigated in different parts of the world for their possible immunomodulatory properties. Some studies demonstrate the isolation of potential bioactive molecules [3].

Macrophages are the first line of defense in the innate immunity against microbial infection, and phagocytes engulf and kill microorganisms and present antigens that elicit adaptive immune responses [26]. Macrophages serve an important function in tissue remodeling through development, wound healing, and tissue homeostasis. Macrophages are essential to the innate immunity and pathology of tissue injury and inflammation [27] through phagocytosis. Macrophages secrete cytokines, such as interleukins, TNF- $\alpha$, and INFs, as well as inflammatory mediators, such as nitric oxide [28]. Macrophages maintain homeostasis and serve an important function in the host defense against pathogens and attacking cells, such as cancer cells [29].
Plant extracts are widely investigated in different parts of the world for their possible immunomodulatory properties. Some studies demonstrated the isolation of potential bioactive molecules [3]. Shosaiko-to, a Japanese herb, possesses many ethopharmacological effects, such as the modulation of numerous host immune responses. Researchers suggest that its effect on hepatitis B might be attributed to its capability to stimulate INFs and activate natural killer cell activity [30].

The effects of $T$. crispa and its isolated fractions on inducing macrophages to release immunomodulatory cytokines, such as INF- $\gamma$, IL-6, and IL-8, were determined. RAW 267.4 macrophage cells were used in this study to determine the immunomodulatory activities by determining their intracellular cytokine production. The results of this study show that T. crispa and its isolated fraction modulate immunity by increasing RAW 264.7 macrophage cell proliferation in a dose-dependent

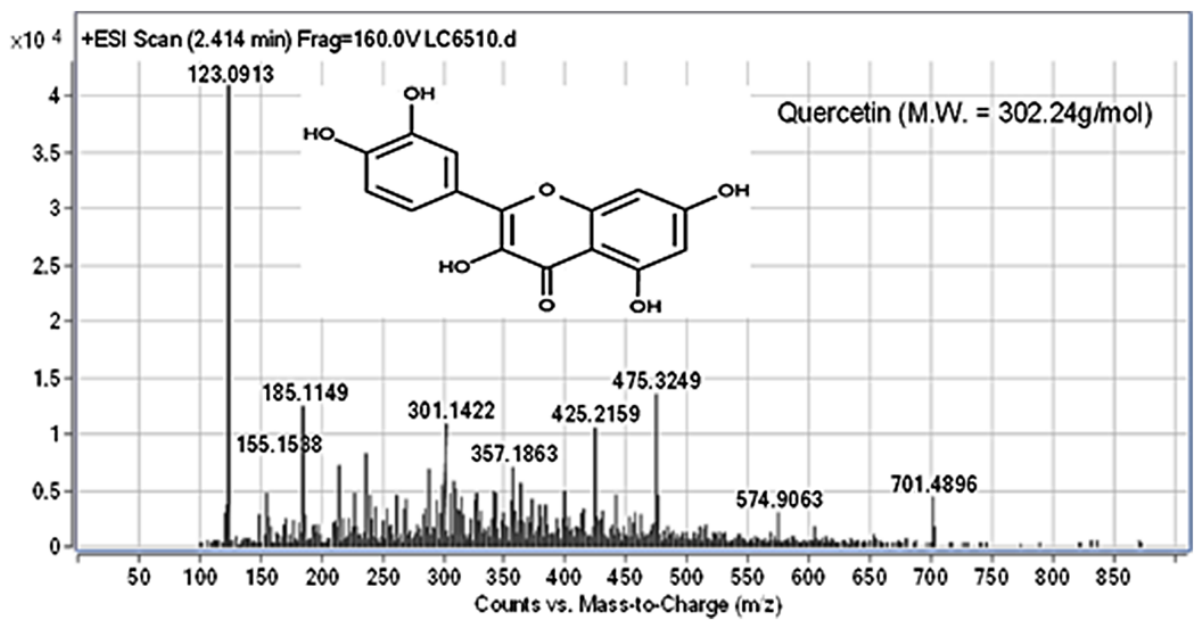

Figure 8 Mass spectrum (TOF MS ES+) and chemical structure of quercetin (peak No. 2) identified in T. crispa F2. 


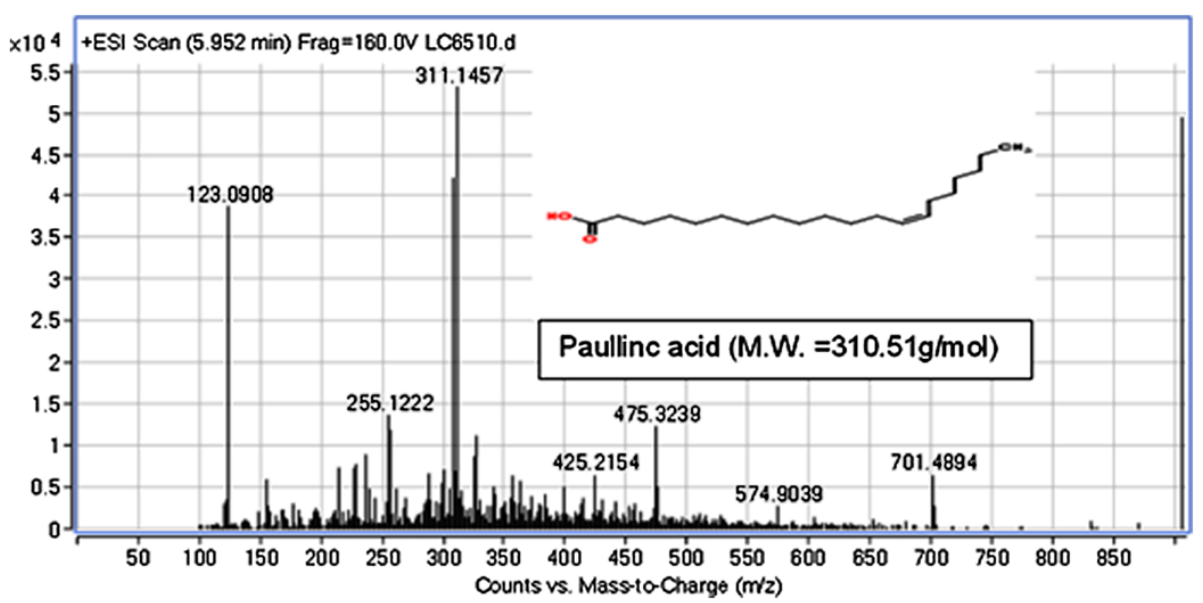

Figure 9 Mass spectrum (TOF MS ES+) and chemical structure of Eicosenoic acid (paullinic acid) (peak No. 3) identified in T. crispa F2.

manner and by significantly inducing the intracellular expression of cytokines INF- $\gamma$, IL-6, and IL-8. These findings clearly indicate the significant immunomodulatory effect of the both the plant and its active fraction as immunostimulators. These findings importantly show that the isolated fraction from T. crispa is a very suitable candidate for modulating macrophage function and inducing the immune system. The literature shows that immunomodulatory action is important in antitumor activity [31]. Therefore, the isolated active fraction from T. crispa in this study is a potential candidate for antitumor treatment. Preliminary studies on the antiproliferative efficiency of the $T$. crispa extract support this hypothesis [32].

The antioxidant activity in the plant has gained significant attention in recent years for its function in protecting cells from damage by oxidative stress. The secondary metabolites of plants are the most biologically active natural compounds. Therefore, plants are sources of food antioxidants, such as vitamin E, vitamin $\mathrm{C}$, phenolic acids, carotenes, and phytoestrogens. Polyphenol or phenolic compounds are secondary metabolites composed of one aromatic ring attached to one or more hydroxyl groups. The molecules range from the simplest molecules of phenolic acid to more complex compounds (polymerized compounds), such as the flavonoids, lignins, and tannins [33,34]. Plants are the major natural sources of polyphenols (flavonoids and non- flavonoids), which give color and flavor to the plants [35]. Phenolic compounds are important in plants because the compounds contribute to the defense against microbes. Flavonoids are involved in UV filtration, symbiotic nitrogen fixation, and floral pigmentation, aside from acting as chemical messengers and regulators of physiological functions. Some flavonoids act as growth inhibitors of organisms that cause plant diseases [36]. T. crispa extract has high antioxidant potential, aside from the high total phenolic and total flavonoid content of the $T$. crispa extract.

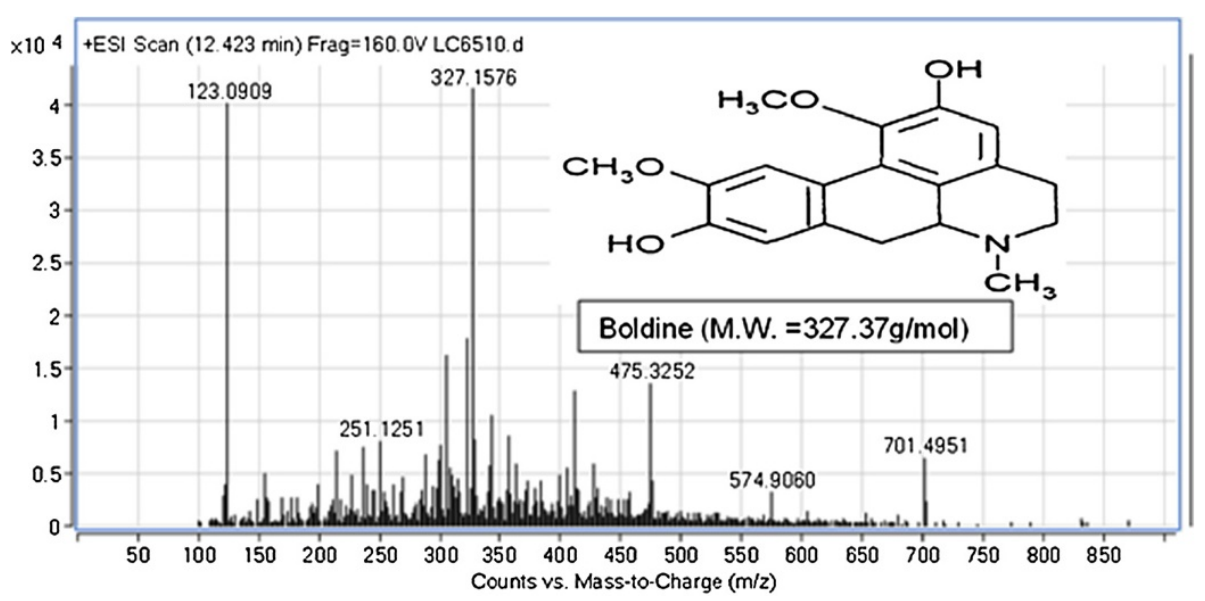

Figure 10 Mass spectrum (TOF MS ES+) and chemical structure of boldine (peak No. 4) identified in T. crispa F2. 
Many previous studies reported the correlation between the antioxidant activity of medicinal plants and their immunomodulatory potential. The phenolic and flavonoid compounds in plants have high antioxidant properties and immunomodulatory effects [37]. The exact mechanism remains unclear, but a large body of evidence supports the influence of antioxidant properties on immunomodulation. In vitro and in vivo studies demonstrated the regulatory effect of phenolic compounds on macrophage modulation and inflammatory mediator secretion from macrophages and other leucocytes [38]. Previous reports show that long-term antioxidant intake increases the antioxidant activity in the thymus, which in turn exhibits enhanced superoxide dismutase and catalase activities [39]. These activities probably stimulate a minor modification towards a mildly oxidizing environment, which favors lymphocyte maturation. The intake of this nutrition may promote the differentiation of other immune cell subsets, such as B cells, T cells, myeloid cells, natural killer cell, and dendritic cells [40].

Inflammation is the response of tissues to injury, characterized in the acute phase through increased blood flow, vascular permeability and the accumulation of fluid, leukocytes and inflammatory mediators, such as cytokines. The immune response in the chronic phase is characterized by the development of specific humoral and cellular immune responses to pathogens at the site of tissue injury. Many soluble factors participated in leukocyte recruitment in the course of the both acute and chronic inflammation processes by increasing the expression of cellular adhesion molecules and chemoattraction. Many kinds these soluble mediators regulate the activation of resident cells, such as fibroblasts, endothelial cells, tissue macrophages, and mast cells. The substances also activated the production of inflammatory cells, including monocytes, lymphocytes, neutrophils, and eosinophils [41]. The results of this study clearly reveal that the treatments using the plant and its fraction enhance immune response and stimulate the production of essential mediator cytokines, such as INF- $\gamma$, IL-6, and IL-8, which are important in the acute and chronic inflammatory response. IL- 6 is important in the stimulation of acute phase protein synthesis in the liver, acts as a growth factor for mature b cells, stimulates their final maturation onto antibody-producing plasma cells, is involved in $\mathrm{T}$ cell activation and differentiation, and affects the induction of IL-2 receptor expression. The functions of IL- 6 in the acute phase response include chronic inflammation, autoimmunity, fibrogenesis, and endothelial cell dysfunction [42]. INF- $\gamma$ affects murine Kupffer cells, stimulates macrophages and is involved in the development of Th1 cells. The cellular effects of INF- $\gamma$ include the up-regulation of pathogen recognition, antigen processing and presentation, inhibition of viruses, inhibition of cellular proliferation, and modifying apoptosis and immunomodulation [43]. IL-8 is a potent neutrophil chemotactic factor. Many types of cells produce large amounts of IL-8 in response to various stimuli, such as pro-inflammatory cytokines, microorganisms and their products, as well as environmental alteration, including hypoxia and hyperoxia. IL- 8 is the main mediator in neutrophil-mediated acute inflammation and has a wide range of actions on the different types of cells, including endothelial cells, fibroblasts, monocytes, lymphocytes, and neutrophils. These functions suggest that IL-8 has important roles in different pathological disorders, such as chronic inflammation and cancer [44]. A previous study [45] revealed that T. crispa has no effect on NK cell activity. However, this study did not suggest that T. crispa does not affect the other immune responses. This study shows that $T$. crispa has an immunostimulatory effect on the activated macrophage mediated by enhancing expression of cytokines INF- $\gamma$, IL-6, and IL-8. These cytokines are involved in lymphocytes cell activation, which may indirectly affect the activation of NK cell type by inducing macrophages to secret the cytokines, which consequently stimulate cell-mediated immunity.

Many previous studies similarly revealed the same effect of medicinal plants, algae, or their derivatives compounds. Astragalus membranaceus polysaccharide improves immune response in the host individual by inducing IL-2, IL-12, and TNF- $\alpha$ secretion, as well as inhibits tumor progression in vivo [46]. Sargassum fusiforme has the same effect in promoting immune response and inhibits the growth of lung adenocarcinoma in mice [47].

LC-MS was performed in this study to detect and identify the possible bioactive components in the $T$. crispa fraction that may have been responsible for its immunomodulatory effect. The LC-MS results for $T$. crispa F2 identified four compounds, including cordioside (C25H34O11), quercetin (C15H10O7), eicosenoic acid (paullinic acid) (C20H38O2), and boldine (C19H21NO4). Cordioside has been isolated from T. crispa, with three other compounds, tinosporaside, columbin, and $\beta$ hydroxyecdysone [48]. Many previous studies reported the isolation and identification of the phenolic compounds, alkaloids, flavonoid, diterpenes, and triterpenes from $T$. crispa and showed their biological activities as highly antioxidant compounds and antiproliferative and anti-inflammatory activities [49]. An alkaloid isolated from T. crispa has cytotoxic activity against Toxoplasma gondii [50]. Borapetoside C, isolated from T. crispa, improved insulin sensitivity in diabetic mice [51]. Praman et al. isolated five compounds (uridine, adenosine, higenamine, salsolinol, and tyramine) from $T$. crispa and proved the effects of these compounds on the cardiovascular system, particularly on the reduction of blood pressure [52]. 
Cordioside and quercetin are flavonoids that have powerful antioxidant activity and many pharmacological applications as immunostimulators and anticancer agents [53].

Eicosenoic acid (paullinic acid) is an omega-7 fatty acid present in various plants. Omega fatty acids are fatty acids that cannot be produced by the human body and are essential for human health. Thus, omega fatty acids must be acquired from food. Omega fatty acids are important in brain function, growth, and development. Research shows the effects of such acids on reducing inflammation and lowering the risk of chronic diseases, such as cancer, heart disease, and arthritis. Omega fatty acid deficiency is accompanied by symptoms, such as poor memory, fatigue, heart problems, dry skin, poor circulation, and depression [54].

Boldine is an alkaloid. Research conducted during the early 1990s showed that boldine is one of the most potent natural antioxidants. Many studies focused on the pharmacological properties of boldine. The antioxidant activity of boldine inspired researchers to investigate its effect as an anticancer, cytoprotective, anti-inflammatory, anti-atherogenic, anti-diabetic, and vasorelaxing immunomodulator [55].

\section{Conclusions}

T. crispa stimulates immune activity by increasing the intracellular expression of cytokines INF- $\gamma$, IL- 6 , and IL-8. The T. crispa fraction was determined through LC-MS phytochemical analysis to contain the compounds cordioside, quercetin, eicosenoic acid (paullinic acid), and boldine, which may be responsible for the immunostimulator potential of T. crispa. Therefore, this plant is a candidate drug that deserves further development and pharmacological studies as a new drug.

\section{Competing interests}

The authors declare there is no competing interest.

\section{Authors' contributions}

WAN is conceived, designed and performed experiments. IF participated in the Flow cytometry part of the study. WNA, MAA and SI wrote and revised the manuscript. All authors read and approved the final manuscript.

\section{Acknowledgements}

This research was supported by the University of Malaya Grant (PV046/2012A).

\section{Author details}

'Department of Biomedical Science, Faculty of Medicine, University of Malaya, 50603 Kuala Lumpur, Malaysia. ${ }^{2}$ Department of Microbiology and Immunology, Faculty of Medicine, University of Diyala, Baqubah, Iraq. ${ }^{3}$ Department of Molecular medicine, Faculty of Medicine, University of Malaya, 50603 Kuala Lumpur, Malaysia. ${ }^{4}$ Institute of Biological Science, Faculty of Science, University of Malaya, 50603 Kuala Lumpur, Malaysia.

Received: 2 January 2014 Accepted: 23 June 2014

Published: 27 June 2014

\section{References}

1. Saroj P, Verma M, Jha K: An overview on immunomodulation. J Adv Sci Res 2012, 3(1):7-12.

2. Mishra K, Ganju L, Sairam M, Banerjee P, Sawhney R: A review of high throughput technology for the screening of natural products. Biomed Pharmacotherapy 2008, 62(2):94-98.

3. Alamgir M, Uddin SJ: Recent advances on the ethnomedicinal plants as immunomodulatory agents. Ethnomed Source Compl Therap 2010, 37/661(2):227-244

4. Mehrotra S, Mishra K, Maurya R, Srimal R, Yadav V, Pandey R, Singh V: Anticellular and immunosuppressive properties of ethanolic extract of Acorus calamus rhizome. Int Immunopharmacol 2003, 3(1):53-61.

5. Lien C, Lean T, Wen C, Mei-Yin C, Chun-Ching L: Immunomodulatory activities of flavonoids, monoterpenoids, triterpinoids, iridoid glycosides and phenolic compounds of plantago species. Planta Med 2003, 69:600-604.

6. Kolm G, Knapp E, Wagner R, Klein D: Lactoferrin, a glycoprotein with immunomodulatory and mast cell stabilising properties, in skin of horses suffering from culicoides hypersensitivity. Res Vet Sci 2007, 83(2):165-170.

7. Gupta VK, Kumar SS: Plants as natural antioxidants. Nat Prod Rad 2006, 5(4):326-334.

8. Yadav DK, Singh N, Dev K, Sharma R, Sharma M, Palit G, Maurya R: Anti-ulcer constituents of Annona squamosa twigs. Fitoterapia 2011, 82:666-675.

9. Dweck AC, Cavin J-P: Andawali (Tinospora crispa): a review. Personal Care Magazine 2006, 7:33-39.

10. Amom Z, Bahari H, Isemaail S, IN A, Shah ZMD, Arsyad MS: Nutritional composition, antioxidant ability and flavonoid content of Tinospora crispa stem. Adv Natural Applied Sci 2009, 3(1):88-94

11. Rungruang $T$, Boonmars $T$ : In vivo antiparasitic activity of the Thai traditional medicine plant-Tinospora crispa-against Plasmodium yoelii. Southeast Asian J Trop Med Public Health 2009, 40(5):898-900.

12. Ihsan SK, Zulkhairi H, Abdah Akim M, Daryl J, Noramalina I, Rasadah MA, Shahidan M, Zamree MS, Kamilah KA, Azrina A, Kamal Mohd NH, Norhaizan ME, Moklas M, Aris M, Hidayat BMT: Antioxidant properties of aqueous and methanol extract from Tinospora crispa and its ability to attenuate hydrogen peroxide-induced stress injury in human umbilical vein endothelial cells. Res J Biol Sci 2011, 6(5):230-236.

13. Ibahim M, Wan-Nor I'zzah W, Narimah A, Nurul AZ, Siti-Nur Shafinas S, Froemming G: Anti-proliperative and antioxidant effects of Tinospora crispa (Batawali). Biomed Res 2011, 22(1):57-62.

14. Amom Z, Md Akim A, Nik Hassan MK, Ibrahim N, Moklas M, Aris M, Bahari H, Fazil MNF, Fairuz Azman K, Kadir A: Biological properties of Tinospora crispa (akar patawali) and its antiproliferative activities on selected human cancer cell lines. Malaysian J Nutri 2008, 14(2):173-187.

15. Trusheva B, Trunkova D, Bankova V: Different extraction methods of biologically active components from propolis: a preliminary study. Chem Central J 2007, 1(13):1-4.

16. Griffina SP, Bhagooli R: Measuring antioxidant potential in corals using the FRAP assay. J Exp Mar Biol Ecol 2004, 302:201-211.

17. Generalic I, Skroza D, Ljubenkov I, Katalinic A, Burčul F, Katalinic V: Influence of the phenophase on the phenolic profile and antioxidant properties of Dalmatian sage. Food Chem 2011, 127:427-433.

18. Ghasemia K, Ghasemia Y, Ebrahimzadehb MA: Antioxidant activity, phenol and flavonoid contents of 13 citrus species peels and tissues. Pak $J$ Pharm Sci 2009, 22(3):277-281.

19. Guan D, Zhang Z, Yang Y, Xing G, Liu J: Immunomodulatory activity of polysaccharide from the roots of Actinidia kolomikta on macrophages. Int J Biol 2011, 3(2):3-10.

20. Gauley J, Pisetsky DS: The release of microparticles by RAW 264.7 macrophage cells stimulated with TLR ligands. J Leukoc Biol 2010, 87(6):1115-1123.

21. Groesdonk HV, Schlottmann S, Richter F, Georgieff M, Senftleben U: Escherichia coli prevents phagocytosis-induced death of macrophages via classical NF-kB signaling, a link to T-cell activation. Infect Immun 2006, 74(10):5989-6000.

22. Gambelli F, Di P, Niu X, Friedman M, Hammond T, Riches DW, Ortiz LA Phosphorylation of tumor necrosis factor receptor 1 (p55) protects macrophages from silica-induced apoptosis. J Biol Chem 2004, 279(3):2020-2029. 
23. Carahera EM, Parenteaub M, Gruberc $\mathrm{H}$, Scott FW: Flow cytometric analysis of intracellular IFN-g, IL-4 and IL-10 in CD3 4 T-cells from rat spleen. $\mathrm{J}$ Immunol Methods 2000, 244(2000):29-40.

24. Connelly L, Palacios-Callender M, Ameixa C, Moncada S, Hobbs AJ: Biphasic regulation of NF-kB activity underlies the Pro- and anti-inflammatory actions of nitric oxide. J Immunol 2001, 166:3873-3881.

25. Salman SM, Heidelberg T, Tajuddin HAB: N-linked glycolipids by Staudinger coupling of glycosylated alkyl diazides with fatty acids. Carbohydr Res 2013, 375(28):55-62.

26. Girotti M, Evans JH, Burke D, Leslie CC: Cytosolic phospholipase A2 translocates to forming phagosomes during phagocytosis of zymosan in macrophages. J Biol Chem 2004, 279(18):19113-19121.

27. Robert C, Lu X, Law A, Freeman TC, Hume DA: Macrophages.com: an on-line community resource for innate immunity research. Immunobiology 2011, 216(11):1203-1211.

28. Stojanovic I, Mirkov I, Kataranovski M, Glamoclija J, Stosic-Grujicic S: A role for macrophage migration inhibitory factor in protective immunity against Aspergillus fumigatus. Immunobiology 2011, 216(9):1018-1027.

29. Gamal-Eldeen AM, Amer H, Helmy WA: Cancer chemopreventive and anti-inflammatory activities of chemically modified guar gum. Chem Biol Interact 2006, 161(3):229-240

30. Borchers AT, Sakai S, Henderson GL, Harkey MR, Keen CL, Stern JS, Terasawa K, Gershwin ME: Shosaiko-to and other Kampo (Japanese herbal) medicines: a review of their immunomodulatory activities. J Ethnopharmaco/ 2000 73(1-2):1-13.

31. Lee S-J, Rim H-K, Jung J-Y, An H-J, Shin J-S, Cho C-W, Rhee YK, Hong H-D, Lee K-T: Immunostimulatory activity of polysaccharides from cheonggukjang. Food Chem Toxicol 2013, 59(2013):476-484.

32. Tungpradit R, Sinchaikul S, Phutrakul S, Wongkham W, Chen S-T: Anti-cancer compound screening and isolation: coscinium fenestratum, Tinospora crispa and Tinospora cordifolia. Chiang Mai J Sci 2010, 37(3):476-488.

33. Calderón-Montaño JM, Burgos-Morón E, Pérez-Guerrero C, López-Lázaro M: A review on the dietary flavonoid kaempferol. Mini-Rev Med Chem 2011, 11(4):298-344

34. Gupta S, KMN S, Duraiswamy B, Chhajed M, Chhajed A: In-vitro antioxidant and free radical scavenging activities of Ocimum sanctum. World J Pharma Res 2012, 1(1):78-92.

35. Luximon-Ramm A, Bahorun T, Soobrattee MA, Aruoma Ol: Antioxidant activities of phenolic, proanthocyanidin, and flavonoid components in extracts of cassia fistula. J Agric Food Chem 2002, 50:5042-5047.

36. Chun S-S, Vattem DA, Lin Y-T, Shett K: Phenolic antioxidants from clonal oregano (Origanum vulgare) with antimicrobial activity against helicobacter pylori. Process Biochem 2005, 40:809-816.

37. Gomez EV, Perez YM, Sanchez HV, Forment GR, Soler EA, Bertot LC, Garcia AY, Vazquez MDRA, Fabian LG: Antioxidant and immunomodulatory effects of viusid in patients with chronic hepatitis C. World J Gastroenterol 2010, 16(21):2638-2647.

38. Ramiro-Puig E, Castell M: Cocoa: antioxidant and immunomodulator. Br J Nutr 2009, 101(07):931-940.

39. Ramiro-Puig E, Urpí-Sardà M, Pérez-Cano FJ, Franch À, Castellote C, Andrés-Lacueva C, Izquierdo-Pulido M, Castell M: Cocoa-enriched diet enhances antioxidant enzyme activity and modulates lymphocyte composition in thymus from young rats. J Agric Food Chem 2007, 55(16):6431-6438.

40. Bhandoola A, Sambandam A: From stem cell to T cell: one route or many? Nat Rev Immunol 2006, 6(2):117-126.

41. Feghali CA, Wright TM: Cytokines in acute and chronic inflammation. Front Biosci 1997, 2(1):d12-d26.

42. Barnes TC, Anderson ME, Moots RJ: The many faces of interleukin-6: the role of IL-6 in inflammation, vasculopathy, and fibrosis in systemic sclerosis. Int J Rheumatol 2011, 2011:1-6.

43. Schroder K, Hertzog PJ, Ravasi T, Hume DA: Interferon- $\gamma$ : an overview of signals, mechanisms and functions. J Leukoc Biol 2004, 75(2):163-189.

44. Mukaida N: Pathophysiological roles of interleukin-8/CXCL8 in pulmonary diseases. Am J Physiol-Lung Cell Mol Physiol 2003, 284(4):L566-L577.

45. Sriwanthana $B$, Chavalittunuong $P$ : In vitro effect of tinospora crispa on cell-mediated immunity. Bull Dep Med Sci 2000, 42(3):193-201.

46. Yang B, Xiao B, Sun T: Antitumor and immunomodulatory activity of Astragalus membranaceus polysaccharides in $\mathrm{H} 22$ tumor-bearing mice. Int J Biol Macromol 2013, 62:287-290.
47. Chen X, Nie W, Yu G, Li Y, Hu Y, Lu J, Jin L: Antitumor and immunomodulatory activity of polysaccharides from Sargassum fusiforme. Food Chem Toxicol 2012, 50(3-4):695-700.

48. Ahmed SM, Manhas LR, Verma V, Khajuria RK: Quantitative determination of four constituents of tinospora sps. By a reversed-phase HPLC-UV-DAD method. Broad-based studies revealing variation in content of four secondary metabolites in the plant from different eco-geographical regions of India. J Chromatogr Sci 2006, 44(8):504-509.

49. Koay YC, Koay F: A review of the secondary metabolites and biological activities of Tinospora crispa (menispermaceae). Trop J Pharm Res 2013, 12(4):641-649.

50. Lee WC, Mahmud R, Noordin R, Piaru SP, Perumal S, Ismail S: Alkaloids content, cytotoxicity and anti-Toxoplasma gondii activity of Psidium guajava L. and Tinospora crispa. Bangladesh J Pharmacol 2012, 7(4):272-276.

51. Ruan C-T, Lam S-H, Chi T-C, Lee S-S, Su M-J: Borapetoside C from Tinospora crispa improves insulin sensitivity in diabetic mice. Phytomedicine 2012, 19(8):719-724

52. Praman S, Mulvany MJ, Williams DE, Andersen RJ, Jansakul C: Hypotensive and cardio-chronotropic constituents of Tinospora crispa and mechanisms of action on the cardiovascular system in anesthetized rats. J Ethnopharmacol 2012, 140(1):166-178.

53. Lu J, Papp LV, Fang J, Rodriguez-Nieto S, Zhivotovsky B, Holmgren A: Inhibition of mammalian thioredoxin reductase by some flavonoids: implications for myricetin and quercetin anticancer activity. Cancer Res 2006, 66(8):4410-4418.

54. Sen DJ: Holistic supplement omega fatty acids: a challenge for smart heart by saying no to atheroscelerosis and yes to homeostasis. J Drug Discov Therap 2013, 1(07):1-13.

55. O'Brien P, Carrasco-Pozo C, Speisky H: Boldine and its antioxidant or health-promoting properties. Chem Biol Interact 2006, 159(1):1-17.

doi:10.1186/1472-6882-14-205

Cite this article as: Abood et al.: Immunomodulatory effect of an isolated fraction from Tinospora crispa on intracellular expression of INF- $\gamma$, IL- 6 and IL-8. BMC Complementary and Alternative Medicine 2014 14:205.

\section{Submit your next manuscript to BioMed Central and take full advantage of:}

- Convenient online submission

- Thorough peer review

- No space constraints or color figure charges

- Immediate publication on acceptance

- Inclusion in PubMed, CAS, Scopus and Google Scholar

- Research which is freely available for redistribution

Submit your manuscript at www.biomedcentral.com/submit
C) Biomed Central 